\title{
Somatic embryogenesis as a tool for virus elimination in Croatian indigenous grapevine cultivars
}

\author{
Nenad Malenica ${ }^{1}$, Mateja Jagić ${ }^{1}$, Bruno Pavletić ${ }^{2}$, Nataša Bauer ${ }^{1}$, Darko Vončina ${ }^{3,4}$, Goran Zdunić ${ }^{5}$, \\ Dunja Leljak Levanić ${ }^{1 *}$ \\ ${ }^{1}$ Division of Molecular Biology, Department of Biology, Faculty of Science, University of Zagreb, Horvatovac 102a, \\ Zagreb, Croatia \\ ${ }^{2}$ Graduate Programme Molecular Biology, Faculty of Science, University of Zagreb, Horvatovac 102a, Zagreb, Croatia \\ ${ }^{3}$ Department of Plant Pathology, Faculty of Agriculture, University of Zagreb, Svetošimunska 25, Zagreb, Croatia \\ ${ }^{4}$ Centre of Excellence for Biodiversity and Molecular Plant Breeding (CroP-BioDiv), Svetošimunska cesta 25, Zagreb, \\ Croatia \\ ${ }^{5}$ Institute for Adriatic Crops and Karst Reclamation, Put Duilova 11, Split, Croatia
}

\begin{abstract}
Most Croatian indigenous grapevine cultivars and vineyards are infected with a few dominant viruses. The goal of this study was to establish somatic embryogenesis as an efficient method for virus elimination from valuable Croatian cultivars and creating a reliable source of healthy plants. Somatic embryogenesis was induced from immature anthers and somatic embryogenesis-derived plantlets for seven indigenous cultivars were successfully regenerated. This procedure led to the elimination of viruses GFLV, GLRaV-1, GLRaV-3 and GFkV that were initially detected in the field-grown cultivars 'Plavac mali' and 'Babica' with an elimination success of at least $30 \%$. The described method has the potential for production of virus-free rooted plantlets for all economically important cultivars or superior cultivar clones and for the establishment of a steady source of certified virus-free planting material.
\end{abstract}

Keywords: Babica, Croatian grapevine cultivars, Plavac mali, RT-PCR, somatic embryogenesis, virus elimination, virus-free plants, Vitis vinifera L.

\section{Introduction}

Grapevine (Vitis vinifera L.) is one of the world's most important fruit species and in Croatia more than a hundred indigenous varieties are an important part of the natural heritage. The national collection of Croatian indigenous cultivars contains 130 accessions, which are the result of a long tradition of grape growing in this area (Maletić et al. 2015). Almost all cultivars are critically endangered since they are, as a rule, grown in very narrow areas, rarely or hardly propagated and represented by fewer than 1000 individuals (Maletić et al. 2015). Furthermore, most Croatian indigenous cultivars and vineyards are infected with at least a few dominant viruses due to the lack of systematic selection and control, as well as long-term propagation of infected materials. Virus-infected vineyards, besides having a shorter life span, show a decrease in quality and quantity of wine produced. For example, the productive life of vineyards infected by Grapevine fanleaf virus (GFLV) is 15-20 years shorter than would otherwise be expected (Andret-Link et al. 2004) and the grapes, must and wine have lower sugar concentration and increased overall acidity, causing economic losses of $80 \%$ (Andret-Link et al. 2004), or even 100\% (Raski et al. 1983). In addition, Croatia as an EU member state has to adopt the use of certified virus-free planting material. Therefore, establishing an efficient method for virus elimination from valuable Croatian cultivars and providing a stable source of healthy plants is urgently needed. Today, about 65 viruses are known to be infective for grapevine, but only a few cause significant economic damage (San Pedro et al. 2017). In Europe, the most damaging virus strains are listed in the classification of the European and Mediterranean Plant Protection Organization (EPPO 2019). The

\footnotetext{
* Corresponding author e-mail: dunja@zg.biol.pmf.hr
} 
most widespread are Grapevine leafroll-associated virus 1, 2 and 3 (GLRaV-1, GLRaV-2 and GLRaV-3), Arabis mosaic virus (ArMV), Grapevine fleck virus (GFkV) and Grapevine fanleaf virus (GFLV) (Vončina et al. 2017, Xiao et al. 2018). According to the propositions of EPPO, certified virus-free vines should be free of these 5 viruses: ArMV, GFLV, GLRaV-1, GLRaV-3 and GFkV (only rootstocks).

Several approaches for virus sanitation have been tested on different grapevine cultivars. The most important elimination technique for viruses and other pathogens from a large number of plant species is apical meristem culture, but it has a limited efficiency in grapes. In general, plant meristem consists of small actively dividing cells located in the central part of the meristematic zone without peripheral leaf primordia. These cells are not connected by the vascular system to the rest of the plant. Active plant cell division and lack of vascular tissue prevent the spread of the virus to the most apical region of the meristem. Success in the isolation of this small virusfree area determines virus elimination efficiency. Therefore, apical meristem isolation is very demanding, since the size of the explant must be as small as possible $(<0.5 \mathrm{~mm}$ for $V$. vinifera) in order to reduce the risk of contact with the vascular system and the virus (Sim and Golino 2010). Moreover, the low survival rate of such small explants in tissue culture (10-30\%), additionally decreases the overall success of the method (Sim 2006). Apical meristem isolation might be combined with exposure of plants to high temperatures (thermotherapy) or application of chemicals (chemotherapy), both slowing down the spread of the viruses. The therapies are commonly used in combination and substantially increase the efficacy of the apical meristem culture-based virus elimination (Wang et al. 2018), but they are frequently connected with new sets of unwanted effects such as phytotoxicity. Moreover, some viruses cannot be eliminated by any of the described meristem-based procedures (Sim 2006).

An alternative method used for virus elimination is somatic embryogenesis (SE). In this process somatic cells give rise to somatic embryos, which develop in a way a way similar to that of their zygotic counterparts. The power of SE as a propagation tool becomes especially apparent when the goal is to generate large numbers of propagules (Barlass and Skene 1978). Successful SE, subsequent maintenance and plantlet regeneration have been established for many species including V. vinifera (Gray and Meredith 1992). It was first demonstrated in 'Cabernet Sauvignon' with the use of nucellar tissue (Mullins and Srinivasan 1976) and later on confirmed on a variety of grape explants such as leaf segments (Robacker 1993), zygotic embryos (Emershad and Ramming 1994), shoot tips (Barlass and Skene 1978), tendrils (Salunkhe et al. 1999), anthers (Stamp and Meredith 1988, Salunkhe et al. 1999), ovaries (Gray and Mortensen 1987) and seeds (San Pedro et al. 2017). The potential of SE in virus elimination is based on the fact that somatic embryos develop from just one somatic cell or a few-celled cluster, where embryos develop separately from the mother plant's vascular system (Newton and Goussard 1990). As in the apical meristem, fast cell divisions during the onset of embryo- genesis and postponed development of vascular system inhibit virus replication, propagation and spread through the newly developed embryo. Somatic embryogenesis could be effective in elimination of almost all viruses (Gambino et al. 2009, 2011) including the recalcitrant "Rugose wood" complex (Gribaudo et al. 2006), which gives SE an important advantage when compared to other methods. On the other hand, SE has some limitations during the induction step as well as the embryo-to-plant conversion step (Goebel-Tourand et al. 1993, López-Pérez et al. 2006). The overall success varies from $0 \%$ in some cultivars to up to $83 \%$ in others (Xu et al. 2005). Also, explant type, composition of the medium, physiological status of donor plant and culture conditions have a remarkable impact (Martinelli et al. 2001, Prado et al. 2010). In conclusion, the standardization of the SE protocol for particular cultivar is rather difficult (Dhekney et al. 2009).

In this work we report the results of a study in which SE was initiated and standardised for a set of seven indigenous Croatian cultivars. Field-grown donor plants and SE-derived plantlets were inspected for the presence of 6 typical viruses GFLV, ArMV, GLRaV-1 -2, -3 and GFkV. The results showed that viruses GFLV, GLRaV-1, -3 and GFkV present in donor plants were successfully eliminated by SE. This is also one of only a few reports that includes detection of viruses in Croatian cultivars by RT-PCR (Vončina et al. 2017), a method that has a higher sensitivity than the routinely used serological ELISA (Gambino and Gribaudo 2006).

\section{Material and methods}

\section{Plant Material}

Plant material was collected from the National Collection of Indigenous Grape Varieties of the Republic of Croatia located in the experimental field at Jazbina (Faculty of Agriculture, University of Zagreb). For explant isolation, inflorescences from Vitis vinifera L. 'Babica,' 'Plavac mali', 'Babić, 'Pošip,' 'Malvazija dubrovačka,' 'Ljutun' and 'Teran' were collected in May and June, 2014 and 2015, approximately 2-3 weeks before anthesis.

Alternatively, explants were isolated irrespective of the season, from dormant vine cuttings (approx. $30 \mathrm{~cm}$ in length), induced to form inflorescence by immerging their basal side into distilled water and exposing them to a $16 \mathrm{~h}$ day/8 h night photoperiod (daylight florescent tube $40 \mathrm{~W}$, 400-700 $\mathrm{nm} 17 \mathrm{Wm}^{-2}$ ) at $26^{\circ} \mathrm{C}$. Identical conditions were used to obtain young leaf material for phenotype and RTPCR analysis of donor plants.

\section{Sterilization and inoculation of explants}

Inflorescences used as explant donors were incubated for 1 minute in $70 \%$ ethanol followed by $2-3$ washes in sterile distilled water. They were then incubated for 10 minutes in $50 \%$ sodium hypochlorite solution ( $1.5 \%$ available chlorine final concentration, Kemika), 0.1\% $\mathrm{Mucasol}^{\circ}$ (Merz Consumer Care $\mathrm{GmbH}$ ) and $0.1 \%$ Tween with constant agitation. Inflorescences were rinsed three times with sterilized 
distilled water in a sterile air-flow cabinet and kept 1-3 days on a wet filter-paper in Parafilm-sealed Petri dishes at $4{ }^{\circ} \mathrm{C}$ prior to explant isolation and culturing.

Anthers were isolated from young buds ( $\varnothing 1.5 \mathrm{~mm})$, and used as explants (Fig. 1A). At that stage, anthers were 0.8 - $1.2 \mathrm{~mm}$ long with yellowish and translucent locules and clear cell walls, representing the most reactive stage for induction of embryogenesis (Dhekney et al. 2009). Individual flower buds were aseptically removed from inflorescence and opened by cutting the basal side of the bud. Filaments were cut at their bases using a thin medical needle (diameter $0.25 \mathrm{~mm}$ ) under the stereomicroscope and together with the attached anthers placed with the adaxial side on top of the solid growth medium. Explants were cultivated at $26^{\circ} \mathrm{C}$ in the dark. Twenty to 25 explants were inoculated per small Petri dish (Ø $30 \mathrm{~mm})$.

\section{Somatic embryo induction and development}

In this study we used MS medium (Murashige and Skoog 1962), NN (Nitsch and Nitsch 1969) and PIV medium (Franks et al. 1998), all described as embryo inductive (Newton and Goussard 1990, Morgana et al. 2004, Xu et al. 2005, Cadavid-Labrada et al. 2008, Dhekney et al. 2009). Media were supplemented with three plant growth regulators (PGRs): 6-Benzylaminopurine (BA), naphthoxyacetic acid (NOA) and 2,4-dichlorophenoxyacetic acid (2,4-D) in different combinations and ratios (Dhekney et al. 2009). In addition, some modifications have been applied to all of the listed media (patent pending, application number RH P20190444, will be published in September 2020). In general, 12 media formulas have been tested in order to identify the most effective combination for the majority of the Croatian grapevine varieties tested. All the media were supplemented with $2 \%(\mathrm{w} / \mathrm{v})$ sucrose and $7 \%(\mathrm{w} / \mathrm{v})$ agar and $\mathrm{pH}$ was adjusted to 5.8 before sterilization. Media were sterilized at $121^{\circ} \mathrm{C}$ and $103 \mathrm{kPa}$ for 15 minutes.

Media for embryo development were of the same composition as those used for embryogenesis induction, with standard MS nitrogen and without PGRs. All media were supplemented with activated charcoal $(0.25 \%)$. Mass of proembryogenic structures, globular and hearth stage embryos were spread individually onto the appropriate medium and cultured in a $16 \mathrm{~h}$ day/ $8 \mathrm{~h}$ night photoperiod (daylight florescent tube $40 \mathrm{~W}, 400-700 \mathrm{~nm} 17 \mathrm{Wm}^{-2}$ ) at $26^{\circ} \mathrm{C}$. Subculturing was done at 4 - to 6-week intervals.

\section{Plant regeneration}

Torpedo stage embryos (apical basal length $2-3 \mathrm{~mm}$ ) were induced to germinate on the embryo germination (EG) medium supplemented with $10 \mu \mathrm{M}$ indole-3-acetic acid (IAA) and $1 \mu \mathrm{M}$ gibberellic acid (GA3) (López-Pérez et al. 2005). Five embryos were placed per Petri dish and cultivated vertically in normal gravitropic root-shoot orientation in the following growth chamber conditions: $26^{\circ} \mathrm{C}$ and $16 / 8 \mathrm{~h}$ photoperiod. Plantlets with well-developed root and green leaves were subsequently transferred to glass test tubes (14 $\times \emptyset 2.5 \mathrm{~cm}$ with $20 \mathrm{ml}$ of EG medium) in order to grow more robust plantlets. After the plantlets developed $5-10 \mathrm{~cm}$ shoot ( $>5$ true leaves), they were planted in small pots $(7 \times 7$ $\mathrm{cm}$ ) filled with a 5:1 soil substrate and sand mixture (Steckmedium, Klassman-Deilmann, Germany) and transferred to Magenta M-7 boxes for acclimatization. Acclimatisation was performed during a 7-10 day period. Immediately after transferring the plantlets to soil, the lids of the Magenta boxes were tightly closed in order to develop high humidity conditions. Starting on the $3^{\text {rd }}$ day, the lid was slightly loosened till day 5 . Then the lid was fully removed and very loosely returned on top of the Magenta box leaving a small space for direct air circulation between the box and the growth chamber. From day 6 to day 10 the air circulation was gradually increased by moving the lid position. On day 11 the lid was fully removed. Well acclimatized plantlets showed vigorous leaf growth during the next 1-2 weeks.

\section{Phenotypic analysis of plants used as source material for somatic embryogenesis}

Colour, chlorotic mottling and leaf deformations were analysed on autumn leaves of naturally growing plants that were used as explant donor and on young leaves induced from dormant cuttings (collected in January 2018).

\section{RNA isolation and RT-PCR}

For total RNA isolation, $50 \mathrm{mg}$ of leaf tissues including leaf veins were collected from both virus-infected and virusfree plants (regenerated through SE) and immediately frozen in liquid nitrogen. Leaves of regenerated plantlets were harvested one year after their acclimatisation to ambient conditions in the growth chamber. Nitrogen frozen tissue was homogenized for 3 minutes in Retsch MM 200 homogenizer at $30 \mathrm{~Hz}$ using four metal beads (

Total RNA was extracted from the samples using a Thermo Scientific MagJET Plant RNA kit following the manufacturer's instructions for manual plant total RNA purification. Lysis Buffer from the kit was supplemented with dithiotreitol (1,4-Dithiothreit, Carl Roth) at final concentration of $0.4 \mathrm{M}$ and polyvinylpyrrolidone (PVP40, Sigma-Aldrich) at a $2 \%$ $(\mathrm{w} / \mathrm{v})$ final concentration.

Modification was made regarding the DNase treatment: $2 \mu \mathrm{g}$ of isolated RNA was treated with DNase I (Amplification grade, Invitrogen) and thereafter the enzyme was inactivated following manufacturer's protocol. RNA purity and concentrations were determined using NanoDropTM 1000 Spectrophotometer (Thermo Scientific).

Isolated total RNA was used for virus detection by a twostep RT-PCR reaction, using six virus-specific primer pairs and a primer pair for $18 \mathrm{~S}$ ribosomal RNA internal control (Tab. 1) (Gambino and Gribaudo 2006). First-strand cDNA was synthesised using $1 \mu \mathrm{g}$ of isolated RNA, 200 units of RevertAid H Minus Reverse Transcriptase, $1 \times$ Reaction Buffer (Thermo Scientific), 50 units of RNase inhibitor (RiboLock, Thermo Scientific), $0.5 \mathrm{mM}$ dNTPs (Sigma-Aldrich) and $1.25 \mu \mathrm{M}$ Random nonamers (Sigma-Aldrich). RT reaction $\operatorname{mix}(20 \mu \mathrm{L})$ was incubated for $50 \mathrm{~min}$ at $37^{\circ} \mathrm{C}$. 
Tab. 1. Primer sequences and expected RT-PCR product sizes.

\begin{tabular}{|c|c|c|c|}
\hline Target & & Primer sequences $5^{\prime}-3^{\prime}$ & Product size (bp) \\
\hline \multirow[t]{2}{*}{$18 \mathrm{~S}$ (internal control) } & Forward & CGCATCATTCAAATTTCTGC & 844 \\
\hline & Reverse & TTCAGCCTTGCGACCATACT & \\
\hline \multirow[t]{2}{*}{ GLRaV-2 } & Forward & GGTGATAACCGACGCCTCTA & 543 \\
\hline & Reverse & CCTAGCTGACGCAGATTGCT & \\
\hline \multirow[t]{2}{*}{ ArMV } & Forward & TGACAACATGGTATGAAGCACA & 402 \\
\hline & Reverse & TATAGGGCCTTTCATCACGAAT & \\
\hline \multirow[t]{2}{*}{ GLRaV-3 } & Forward & TACGTTAAGGACGGGACACAGG & 336 \\
\hline & Reverse & TGCGGCATTAATCTTCATTG & \\
\hline \multirow[t]{2}{*}{ GLRaV-1 } & Forward & TCTTTACCAACCCCGAGATGAA & 232 \\
\hline & Reverse & GTGTCTGGTGACGTGCTAAACG & \\
\hline \multirow[t]{2}{*}{ GFkV } & Forward & TGACCAGCCTGCTGTCTCTA & 179 \\
\hline & Reverse & TGGACAGGGAGGTGTAGGAG & \\
\hline \multirow[t]{2}{*}{ GFLV } & Forward & ATGCTGGATATCGTGACCCTGT & 118 \\
\hline & Reverse & GAAGGTATGCCTGCTTCAGTGG & \\
\hline
\end{tabular}

For each target virus or gene, PCR reaction mix ( $25 \mu \mathrm{l})$ was prepared using $2 \mu \mathrm{l}$ of cDNA, $0.2 \mu \mathrm{M}$ of each virus-specific primer, 1 unit of GoTaq Flexi DNA polymerase, $1 \times$ GoTaq Flexi Buffer (Promega), 0.2 mM dNTPs (Sigma-Aldrich) and 2,5 $\mathrm{mM} \mathrm{MgCl}_{2}$ (Thermo Fisher Scientific). Cycling conditions for all primer sets were as follows: initial denaturation at $95^{\circ} \mathrm{C}$ for $2 \mathrm{~min}, 35 \mathrm{cycles}$ at $95^{\circ} \mathrm{C}$ for $30 \mathrm{~s}, 57^{\circ} \mathrm{C}$ for $30 \mathrm{~s}$ and $72^{\circ} \mathrm{C}$ for 1 minute, ending with a final elongation at $72{ }^{\circ} \mathrm{C}$ for 5 minutes.

Reaction products were analysed by electrophoresis on a $2.5 \%$ agarose gel $(1 \times$ TAE buffer $)$ and visualised by UV light after staining in ethidium bromide.

\section{Results}

\section{Induction of somatic embryogenesis}

In this study, 'Plavac mali' has been chosen as a priority cultivar for virus elimination because it belongs to the group of the most endangered Croatian cultivars (Maletić et al. 2015) and has a high importance for vine production. Immature anthers in developmental stage 2 and 3 (Fig.1A) were cultivated on MS (Murashige and Skoog 1962), NN (Nitsch and Nitsch 1969) and PIV (Franks et al. 1998) media. Unfortunately, none of them could induce SE in 'Plavac mali. We further tested different modifications of ammonium and nitrate composition (Leljak and Jelaska 1995) and different 2,4-D, NOA and BA ratios to determine the most inductive formula. Eventually, the appropriate media composition, further designated as NMM medium (patent pending), enabled good explant reactivity in which 18/200 (9\%) explants developed embryogenic calli within the first month in culture (5 explants) or later (13 explants) (Fig. 1B-D, Tab. 2 ). The explant response in 'Plavac mali' was visible as unorganized growth along the filament as soon as 2 weeks after the explant inoculation (Fig. 1B). Four weeks later, embryogenic structures were formed (Fig. 1C), while after 6-8 weeks of culturing, a sufficient amount of embryos were obtained and used for the induction of next developmental stages (Fig. 1D). The same procedure was applied for the induc-
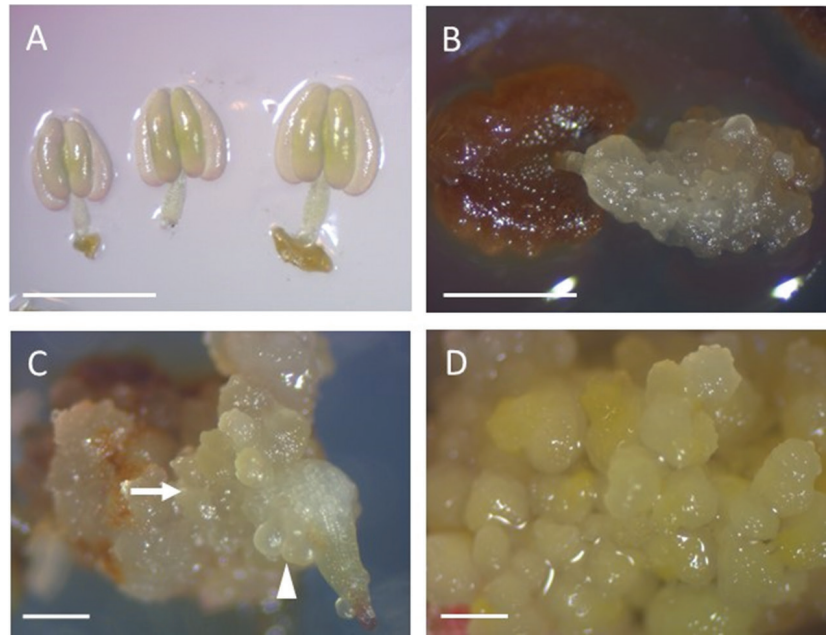

Fig. 1. Time course of somatic embryo induction on immature anther explants of 'Plavac mali' cultivated on a new medium formula designated NMM. Immature anthers of stage 2 (A, left) and 3 (A, right). Formation of callus on stamen filament after 2 weeks of culturing (B). Appearance of embryogenic structures after 4 weeks: proembryogenic masses (arrow) and globular embryos (C, arrowhead). Embryogenic callus dominantly consist of globular embryos 8 weeks after explant inoculation (D). Size bar: $1 \mathrm{~mm}$.

tion of SE in other Croatian indigenous cultivars: 'Malvazija dubrovačka' (Fig. 2A), 'Teran' (Fig. 2B), 'Babica' (Fig. 2C), 'Pošip' (Fig. 2D), 'Babić' (Fig. 2E) and 'Ljutun' (Fig. 2F). The highest efficiency of somatic embryogenesis was obtained in 'Babica' (70\%) while, next to 'Plavac mali' the lowest efficiency of $16 \%$ was obtained in 'Malvazija dubrovačka' (Tab. 2).

\section{Development of somatic embryos}

Beside the appearance of proembryogenic mass, during the cultivation on the induction medium NMM, some embryogenic structures developed further into globular and hearth stage embryos. Pronounced embryo maturation was established after removal of PGRs from the NMM composition and the addition of $0.25 \%$ activated charcoal. Approxi- 

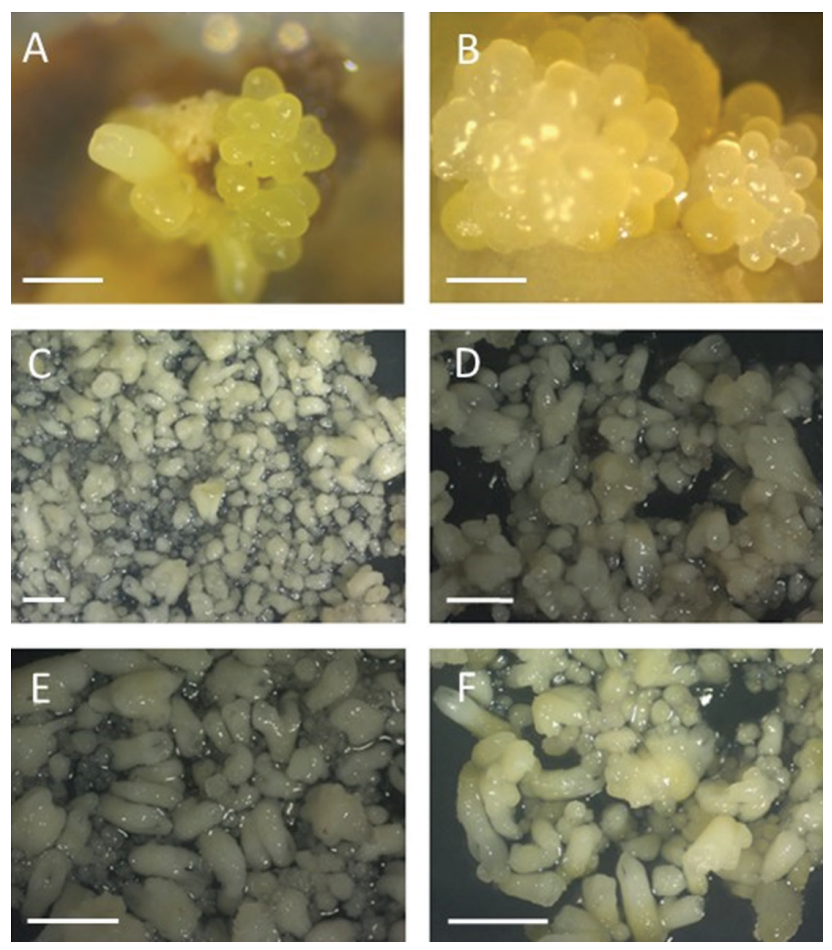

Fig. 2. Embryogenic calli of different cultivars during the cultivation on induction medium (A, B) and medium for embryo development (C - F). 'Malvazija dubrovačka' (A), 'Teran' (B), 'Babica' (C), 'Pošip' (D), 'Babić' (E) and 'Ljutun' (F). Embryogenic callus dominantly consists of globular embryos (A, B) or torpedo stage embryos (C F). Size bars: $1 \mathrm{~mm}(\mathrm{~A}, \mathrm{~B}), 5 \mathrm{~mm}(\mathrm{C}, \mathrm{D})$ and $2 \mathrm{~mm}(\mathrm{E}, \mathrm{F})$. mately two weeks after subculturing of the embryogenic calli onto embryo development medium, globular, heart and torpedo stage embryos were predominantly formed (Fig. 2CF). Some embryos sporadically developed well-formed cotyledons. After removing a single torpedo stage embryo from the underlying callus, a narrowed point of attachment reminiscent of suspensor was apparent (Fig. 3A) as previously described by Jayasankar et al. (2003). The embryos were not attached to each other, so their separation was simple and did not damage their structures. For transfer to germination medium, we used 1-3 mm torpedo stage embryos in the apical-basal orientation (Fig. 3A) or early cotyledonary embryos (Fig. 3B).

\section{Plantlets regeneration}

After transferring torpedo or cotyledonary stage embryos onto EG medium, they were able to form embryogenic root and cotyledons on the opposite poles, acquiring a clear root-shoot axis followed by hypocotyl elongation and development of green cotyledons. Development was continued until the emergence of the first leaves (Fig. 3C) when they were transferred from Petri dishes to glass test tubes. After 3 to 4 weeks, they reached a height of approximately $2-3 \mathrm{~cm}$ (Fig. 3D, E). For each cultivar ten somatic embryo-derived plantlets were transferred from Petri dishes to test tubes, magenta boxes and finally acclimatised to grow in growth chamber conditions (Fig. 3F, G).
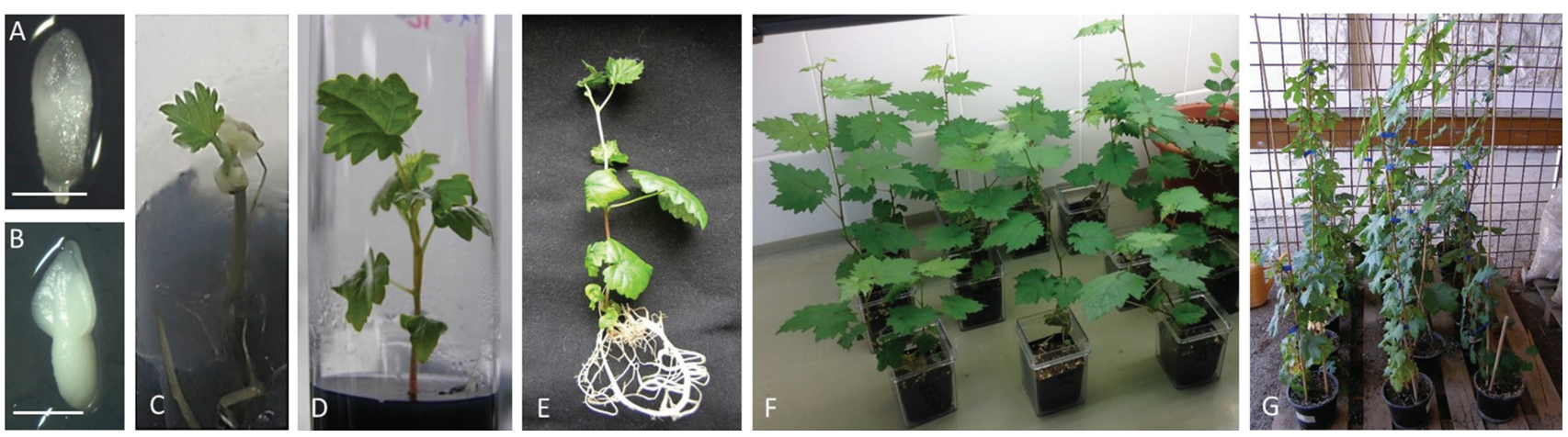

Fig.3. Regeneration of somatic embryos in cultivar 'Plavac mali. Torpedo (A) and cotyledonary (B) stage embryos. Young plantlets with first leaf formed (C). Plantlets with well developed shoot and root of approximately $6 \mathrm{~cm}(\mathrm{D}, \mathrm{E})$. Acclimatised plants grown in pots: growth chamber $(F)$ or outside $(\mathrm{G})$. Size bar: $1 \mathrm{~mm}$.

Tab. 2. Efficiency of somatic embryogenesis induction in different Croatian indigenous Vitis vinifera L. cultivars expressed as a percentage of reactive explants. Fast embryogenic response includes appearance of embryogenic structures within first month of cultivation while later appearance of embryogenic callus is considered as prolonged.

\begin{tabular}{lcccc}
\hline Cultivar & No. of explants & $\begin{array}{c}\text { No. of explants with embryogenic } \\
\text { response Fast/Prolonged }\end{array}$ & $\begin{array}{c}\text { \% of explants with } \\
\text { embryogenic response }\end{array}$ & $\begin{array}{c}\text { No. of regenerated } \\
\text { plantlets }\end{array}$ \\
\hline Plavac mali & 200 & $5 / 13$ & 9 & 10 \\
Babić & 50 & $14 / 13$ & 54 & 3 \\
Babica & 50 & $17 / 18$ & 70 & 10 \\
Ljutun & 50 & $12 / 21$ & 66 & 3 \\
Malvazija dubrovačka & 50 & $0 / 8$ & 16 & 3 \\
Pošip & 50 & $18 / 12$ & 6 & 3 \\
Teran & 50 & $15 / 14$ & 58 & 3 \\
\hline
\end{tabular}




\section{Sanitary status of outdoor growing plants used as explant donors}

Sanitary statuses of vines used as explant donors for cultivars 'Babica' and 'Plavac mali' were analysed. Clearly visible phenotypic characteristics of infection (Martelli 1993, Andret-Link et al. 2004, Meng et al. 2017) were obvious on leaves of both cultivars (Fig. 4A-D). In 'Babica' the area around the leaf veins was darker and the edges were twisted downwards (Fig. 4A). In mature leaves anthocyanin accumulation was pronounced (Fig. 4B). Although a widely used method for virus detection is based on serological tests (enzyme-linked immunosorbent assay - ELISA), here we used the more sensitive reverse transcription polymerase chain reaction - RT-PCR (Gambino and Gribaudo 2006) to test the presence of six dominant grapevine viruses: GFLV, ArMV, GLRaV-1 -2, -3 and GFkV. The results showed that the phenotype of 'Babica' described was provoked by the presence of GLRaV-3 and GFLV viruses, since both were detected in donor plants (Fig. 4E). The presence of a symptomless GFkV (Bota et al. 2014) was also detected by RT-PCR.

The mature leaves of $V$. vinifera 'Plavac mali' showed the most pronounced disease symptoms. Such results were confirmed by RT-PCR analysis. Namely, in all $V$. vinifera 'Plavac mali' plants with significant phenotypic symptoms of infection, among six viruses tested for, three (GLRaV-1, GLRaV-3 and GFLV) were detected. As described above, the twisted edges and darkening of the vein area in young and older leaves of 'Plavac mali' (Fig. 4C, D) are symptoms characteristic of viruses from the leafroll complex (GLRaVs). RTPCR analysis demonstrated that the symptoms of $V$. vinifera 'Plavac mali' are likely to be caused by GLRaV-1 and GL$\mathrm{RaV}-3$. Similarly, the pronounced chlorosis of mature leaves (Fig. 4D) was caused by GFLV infection.

\section{Sanitary status of somatic embryogenesis derived plantlets}

Three out of ten SE-derived plantlets of cultivars 'Babica' and 'Plavac mali' were randomly selected for sanitary status analysis. Virus presence in SE-derived plants was determined by RT-PCR with the same parameters already used for explant donor plants. The results showed that for 'Babica' two out of three plantlets were completely free of three viruses (Fig. 5A) previously detected in donor plants. The third plant was still infected with GFLV (Fig. 5B). Similar results were obtained with the cultivar 'Plavac mali', in which one plant was completely virus-free (Fig. 5C) while two plants were still infected by GFLV (Fig. 5D).

\section{Discussion}

\section{Somatic embryogenesis and plantlets regeneration}

There are several reports on SE regeneration system in Vitis showing that a series of factors such as the genotype, the developmental stage and type of explant, physiological and sanitary status of donor plants, culture media and PGR composition all affect efficiency of the method (Martinelli and Gribaudo 2001). Immature anthers at developmental stage 2 and 3, used in our work as explants, were previously shown as the most reactive explant type regarding SE success in different grapevine cultivars (Cadavid-Labrada et al. 2008, Dhekney et al. 2009). Moreover, MS (Murashige and Skoog 1962), NN (Nitsch and Nitsch 1969) and PIV (Franks et al. 1998) media were previously described as embryo-inductive for the majority of tested $V$. vinifera cultivars (Newton and Goussard 1990, Morgana et al. 2004, Xu et al. 2005, Cadavid-Labrada et al. 2008). None of them was embryoinductive for the Croatian cultivars tested. Consequently, we
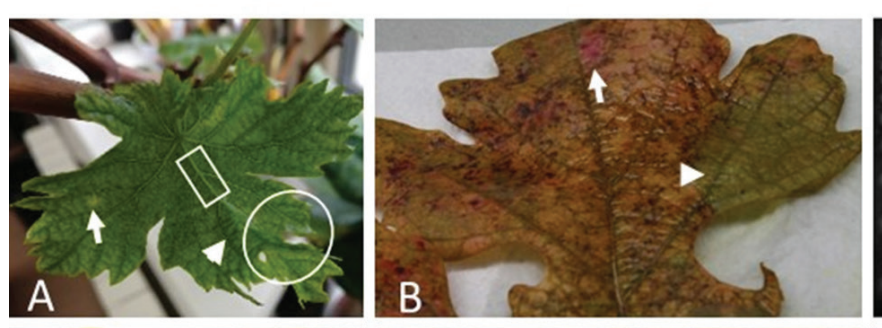

M GLRaV2 ArMV GLRaV3 GLRaV1 GFkV GFLV $18 \mathrm{~S} \quad \mathrm{NC}$
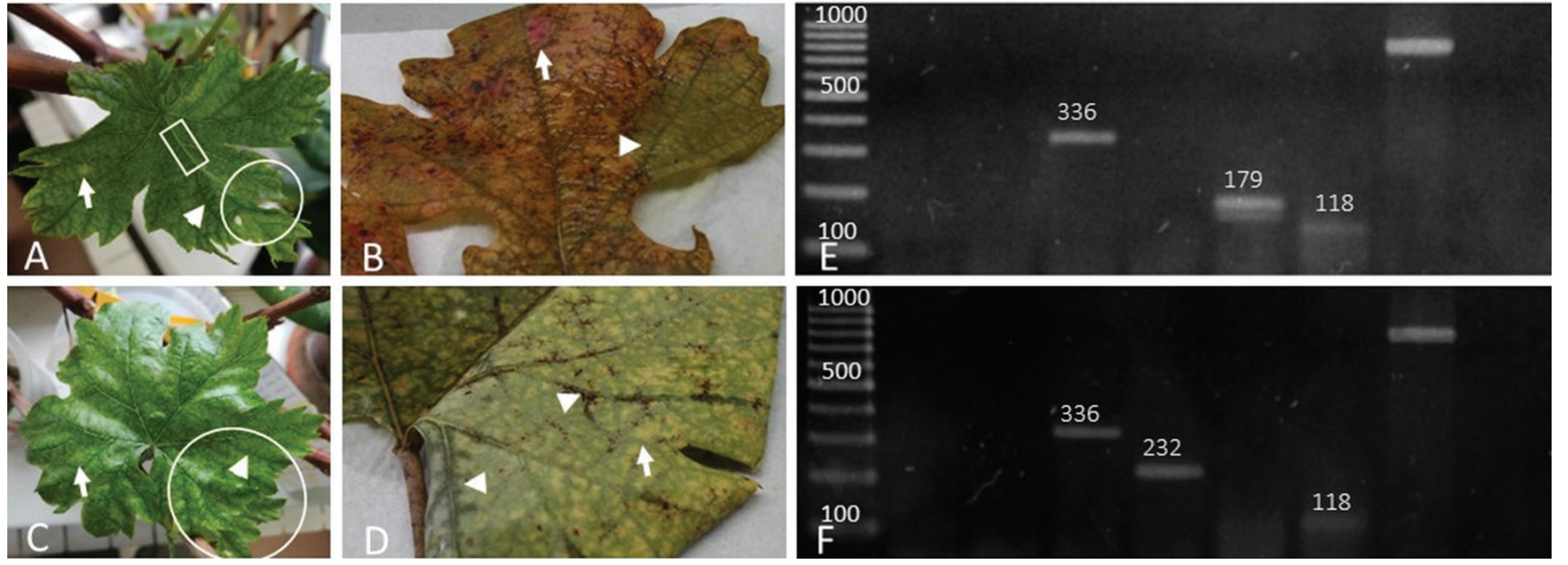

Fig. 4. Phenotypic and RT-PCR-based analysis of virus infection in 'Babica' and 'Plavac mali'. (A) Young leaf developed from winter buds of 'Babica' with obvious fan-like morphology and downward leaf distortion (circled), dark green vein area (arrowhead) with vein yellowing (boxed) and mosaic yellow chlorosis (arrow). (B) Mature leaf from field-grown 'Babica' with anthocyanin accumulation (arrow) and darkened veins (arrowhead). (C) Young leaf developed from winter buds of 'Plavac mali' with obvious fan-shaped edges (circled), darkened vein area (arrowhead) and yellow mosaic chlorosis (arrow). (D) Mature leaf from field-grown 'Plavac mali' with prominent chlorosis (arrow) and darkened vein area (arrowhead). RT-PCR analysis of Grapevine leafroll-associated viruses (GLRaV-1, GLRaV-2 and GLRaV-3), Arabis mosaic virus (ArMV), Grapevine fleck virus (GFkV) and Grapevine fanleaf virus (GFLV) in 'Babica' (E) and 'Plavac mali' (F). NC - negative control: $18 \mathrm{~S}$ rDNA - positive control. Bends with numbers are amplified viruses. Numbers are fragments size in bp. 

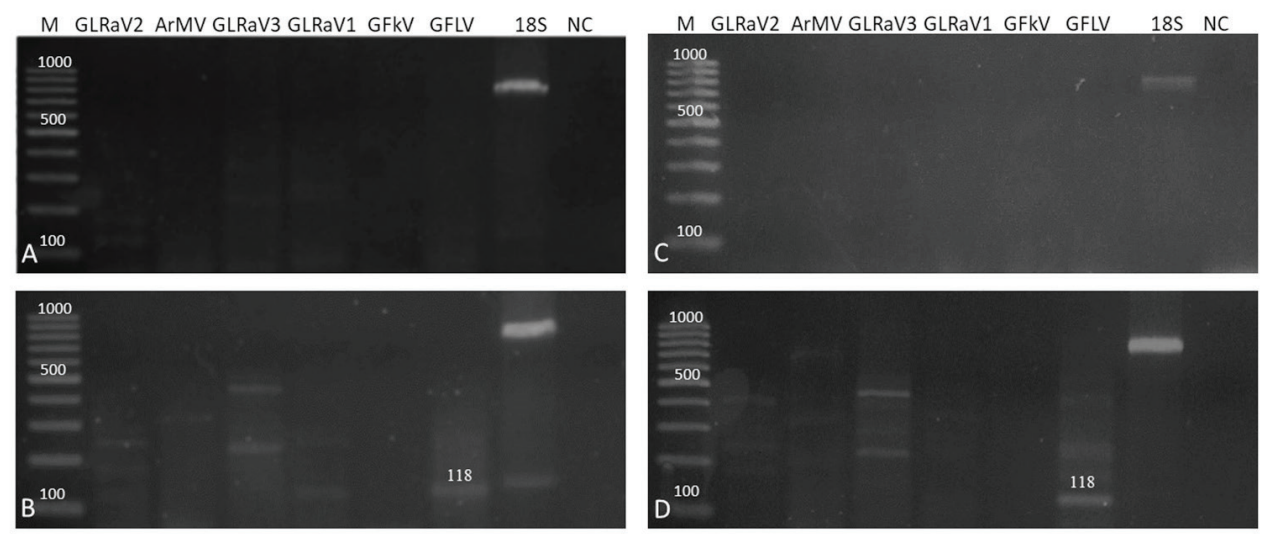

Fig. 5. RT-PCR analysis of Grapevine leafroll-associated viruses (GLRaV-1, GLRaV-2 and GLRaV-3), Arabis mosaic virus (ArMV), Grapevine fleck virus (GFkV) and Grapevine fanleaf virus (GFLV) in on 'Babica' and 'Plavac mali' regenerants obtained by somatic embryogenesis. Healthy plants of 'Babica' (A) and 'Plavac mali' (C). GFLV-infected regenerants of 'Babica' (B) and 'Plavac mali' (D). Visible unlabelled fragments do not correspond to the expected virus specific sizes and are products of unspecific amplification. NC - negative control, $18 \mathrm{~S}$ rDNA - positive control. Numbers represent a fragment size in bp.

tested different modifications of listed media regarding ammonium and nitrate composition (Leljak and Jelaska 1995) as well as different 2,4-D, NOA and BA ratios to determine the most inductive formula for the seven Croatian grapevine cultivars. The composition of nitrogen sources and PGRs in newly established NMM medium enabled a rather low somatic embryo induction in 'Plavac mali' and 'Malvazija dubrovačka', while in other tested cultivars explant reactivity was higher than $50 \%$. The obtained high levels of embryogenesis induction in most of the cultivars are in agreement with somatic embryogenesis efficiency higher than $80 \%$ or $27 \%$ as described in Cadavid-Labrada et al. (2008) and Morgana et al. (2004), respectively. Morgana et al. (2004) suggest stigma/style explants as a more favourable type for somatic embryogenesis while Cadavid-Labrada et al. (2008) and Dhekney et al. (2009) emphasize anthers as the most advantageous type of explant. Dhekney et al. (2009) demonstrated in their work that anthers are more suitable than pistils; embryogenesis was successfully induced in 25 out of the 26 cultivars when anthers were used compared to 22 reactive cultivars in experiments on pistils, thus rejecting hypotheses that female organs are the most responsive explants (Kikkert et al. 2005). In our work with 'Plavac mali', embryogenesis was not obtained when ovules or pistils were used (data not shown). While in previous reports induction medium is adjusted for each particular cultivar (eg. 'Sugraone' in Morgana et al. 2004; 'Carménére' in Cadavid-Labrada et al. 2008), we succeeded in developing only one medium formula for seven cultivars. It should be noted that in our work we used as explants the most reactive developmental stages of immature anthers. This additionally increased the rate of the reactivity, compared to those obtained in Dhekney et al. (2009).

The onset of embryogenesis was characterised with tissue proliferation along anther filaments which coincide with the results of Faure et al. (1996) who showed that grapevine anther cultures usually produce embryogenic tissue from diploid cells of filament connective tissues. This somatic ori- gin of embryogenic tissue is important for enabling progeny genetically identical to the mother plant (Faure et al. 1996) thus preserving cultivar identity.

Finally, our goal was to find a medium with potential for the induction of SE in most of the tested Croatian cultivars. In conclusion, our newly established formula (NMM) enables induction of embryogenesis in all tested cultivars. After removal of PGRs, pronounced maturation was induced, and globular, heart and torpedo stage embryos were predominantly formed. Further development of embryos includes hypocotyl elongation and development of green cotyledons (Cadavid-Labrada et al. 2008). Since germination and plantlet regeneration were higher than $80 \%$, this was not a limiting step in our report, or in the reports of others (Cadavid-Labrada et al. 2008). Interestingly, in contrast to the previously reported need for dormancy breaking treatment like stratification (Jayasankar et al. 2003), in our work the addition of GA3 to germination media was sufficient for direct germination without a stratification period (Pearce et al. 1987).

\section{Sanitary status of field-grown plants used as explant donors}

Phenotypic analysis was done on leaves induced from dormant vine cuttings as well as on autumn leaves of fieldgrown 'Babica' and 'Plavac mali' that were used as explant donors. The clearly visible phenotypic characteristics of infection were a darker area around the leaf veins and downward-twisted leaf edges (Martelli 1993, Andret-Link et al. 2004, Meng et al. 2017). Both symptoms are characteristic of red varieties infected with the most widespread and damaging viruses (Alliaume et al. 2018, Sabella et al. 2018) of the leafroll complex (Meng et al. 2017). In the advanced phase of infection, the viruses of the leafroll complex cause anthocyanin accumulation. Presence of yellow mosaic chlorosis, fan-like morphology and vein yellowing (Oliver and Fuchs 2011) indicate presence of GFLV. RTPCR analysis confirmed that described phenotypes were 
provoked by presence of GLRaV-3 and GFLV. The presence of GFkV is not connected to the visible symptoms since it is an symptomless virus for grape (Bota et al. 2014). By SE regeneration, we obtained at least one completely virus-free plantlet out of three tested while the other plants remained infected only with GFLV. GFLV is a soil-borne nepovirus and the main agent of the most damaging and widespread viral diseases affecting grapevine (Gambino et al. 2009). In sensitive cultivars this nepovirus can cause rapid death of young plants or a progressive decline over several years (Martelli 1993). In contrast to phloem-limited viruses, GFLV and other nepoviruses readily invade meristems, embryogenic calli (lacking vascular system) and embryo-derived plantlets. Neither the meristem culture nor SE are efficient enough for its eradication without additional thermotherapy (Goussard and Wiid 2017). In contrast, Gambino et al. (2009) showed that GFLV elimination is possible without thermotherapy, which according to the authors was enabled by prolonged exposure of explants and calli to auxins and cytokinins that have detrimental effects on some viruses (Clarke et al. 1998). In our study, the exposure to PGRs was shortened to provide maximum cytological and genetic stability during cultivation (Bennici et al. 2004, Morgana et al. 2004). Therefore, we can assume that complete virus elimination is possible in other

\section{References}

Alliaume, A., Reinbold, C., Erhardt, M., Beuve, M., Hily, J.M., Lemaire, O., Herbach, E., 2018: Virus preparations from the mixed-infected P70 Pinot Noir accession exhibit GLRaV-1/ GVA 'end-to-end' particles. Archives of Virology 163, 31493154.

Andret-Link, P., Laporte, C., Valat, L., Ritzenthaler, C., Demangeat, G., Vigne, E., Laval, V., Pfeiffer, P., Stussi-Garaud, C., Fuchs, M., 2004: Grapevine fanleaf virus: Still a major threat to the grapevine industry. Journal of Plant Pathology 86, 183-195.

Barlass, M., Skene, K.G.M., 1978: In vitro propagation of grapevine (Vitis vinifera L.) from fragmented shoot apices. Vitis 17, 335-340.

Bennici, A., Anzidei, M., Vendramin, G.G., 2004: Genetic stability and uniformity of Foeniculum vulgare Mill. regenerated plants through organogenesis and somatic embryogenesis. Plant Science 166, 221-227.

Bota, J., Cretazzo, E., Montero, R., Rosselló, J., Cifre, J., 2014: Grapevine fleck virus (GFkV) elimination in a selected clone of Vitis vinifera L. CV. Manto Negro and its effects on photosynthesis. Journal International des Sciences de la Vigne et du Vin 48, 11-19.

Cadavid-Labrada, A., Medina, C., Martinelli, L., Arce-Johnson, P., 2008: Somatic embryogenesis and efficient regeneration of Vitis vinifera L. "Carménère" plants. Vitis 47, 73-74.

Clarke, S.F., Burritt, D.J., Jameson, P.E., Guy, P.L., 1998: Influence of plant hormones on virus replication and pathogenesis-related proteins in Phaseolus vulgaris L. infected with white clover mosaic potexvirus. Physiological and Molecular Plant Pathology 53, 195-207.

Dhekney, S.A., Li, Z.T., Compton, M.E., Gray, J.D., 2009: Optimizing Initiation and Maintenance of Vitis Embryogenic Cultures. HortScience 44, 1400-1406. cultivars, but it is necessary to carry out further testing on a wider number of regenerated plants.

Taken together, our protocol enabled regeneration of seven Croatian cultivars through somatic embryogenesis within 10 to 12 weeks. In addition, for two tested cultivars we obtained at least one plantlet cleaned of all viruses that were initially detected in the donor plants.

By using our virus elimination protocol in combination with nodal segment propagation, it is possible to obtain a high number of healthy plantlets from just one healed SEderived plant in a rather short period of time. Therefore, our results are of great importance with respect to the further development of virus elimination methodology and for the establishment of a steady source of certified virus-free planting material for Croatian vineyards.

\section{Funding}

This work was supported through institutional projects financed by the University of Zagreb.

\section{Acknowledgements}

We are grateful to Ana-Marija Boljkovac for technical contribution and Darko Preiner, Domagoj Stupić and Edi Maletić for providing the plant material.
Emershad, R.L., Ramming, D.W., 1994: Somatic embryogenesis and plant development from immature zygotic embryos of seedless grapes (Vitis vinifera L.). Plant Cell Reports 14, 6-12.

EPPO (2019) European and Mediterranean Plant Protection Organization. Retrieved April 11, 2019 from https://gd.eppo.int/.

Faure, O., Aarrouf, J., Nougarède, A., 1996: Ontogenesis, differentiation and precocious germination in anther-derived somatic embryos of grapevine (Vitis vinifera L.): Proembryogenesis. Annals of Botany 78, 23-28.

Franks, T., He, D.G., Thomas, M., 1998: Regeneration of transgenic Vitis vinifera L. Sultana plants: genotypic and phenotypic analysis. Molecular Breeding 4, 321-333.

Gambino, G., Gribaudo, I., 2006: Simultaneous detection of nine grapevine viruses by multiplex reverse transcription-polymerase chain reaction with coamplification of a plant RNA as internal control. Phytopathology 96, 1223-1229.

Gambino, G., Di Matteo, D., Gribaudo, I., 2009: Elimination of Grapevine fanleaf virus from three Vitis vinifera cultivars by somatic embryogenesis. European Journal of Plant Pathology $123,57-60$.

Gambino, G., Navarro, B., Vallania, R., Gribaudo, I., Di Serio, F., 2011: Somatic embryogenesis efficiently eliminates viroid infections from grapevines. European Journal of Plant Pathology $130,511-519$.

Goebel-Tourand, I., Mauro, M.C., Sossountzov, L., Miginiac, E., Deloire, A., 1993: Arrest of somatic embryo development in grapevine: histological characterization and the effect of $A B A$, BAP and zeatin in stimulating plantlet development. Plant Cell, Tissue and Organ Culture 33, 91-103.

Goussard, P.G., Wiid, J., 2017: The elimination of fanleaf virus from grapevines using in vitro somatic embryogenesis combined with heat therapy. South African Journal of Enology and Viticulture 13, 81-83. 
Gray, D.J., Mortensen, M.E., 1987: Grape somatic embryo dormancy and quiescence: Potential of dehydrated aynthetic seeds for germplasm conservation. In: Rodenbaugh, K. (ed.), Applications of synthetic seeds for germplasm conservation, 367-379. CRC Press, London, Tokyo.

Gray, D.J., Meredith, C.P., 1992: Grape. In: Hammerschlag, F.A., Litz, R.E. (eds.), Biotechnology of perennial fruit crops, 229262. C.A.B. International, Wallingford, UK.

Gribaudo, I., Gambino, G., Cuozzo, D., Mannini, F., 2006: Attempts to eliminate Grapevine rupestris stem pitting-associated virus from grapevine clones. Journal of Plant Pathology 88, 293-298.

Jayasankar, S., Bondada, B. R., Li, Z., Gray, D.J., 2003: Comparative anatomy and morphology of Vitis vinifera (Vitaceae) somatic embryos from solid- and liquid-culture-derived proembryogenic masses. American Journal of Botany 90, 973-979.

Kikkert, J.R., Striem, M.J., Vidal, J.R., Wallace, P.G., Barnard, J., Reisch, B.I., 2005: Long-term study of somatic embryogenesis from anthers and ovaries of 12 grapevine (Vitis sp.) genotypes. In Vitro Cellular and Developmental Biology - Plant $41,232-239$.

Leljak, D., Jelaska, S., 1995: Callus formation and somatic embryo production in pumpkin Cucurbita pepo L. explants on hormone-free medium. Periodicum Biologorum 97, 327-332.

López-Pérez, A.J., Carreno, J., Dabauza, M., 2006: Somatic embryo germination and plant regeneration of three grapevine cvs: Effect of IAA, $\mathrm{GA}_{3}$ and embryo morphology. Vitis 45, 141-143.

López-Pérez, A.J., Carreño, J., Martínez-Cutillas, A., Dabauza, M., 2005: High embryogenic ability and plant regeneration of table grapevine cultivars (Vitis vinifera L.) induced by activated charcoal. Vitis 44, 79-85.

Maletić, E., Karoglan Kontić, J., Pejić, I., Preiner, D., Zdunić, G., Bubola, M., Stupić, D., Andabaka, Ž., Marković, Z., Šimon, S., 2015: Green Book: Indigenous grapevine varieties of Croatia. State Institute for Nature Protection, Zagreb, Croatia.

Martelli, G., 1993: Graft-transmissible diseases of grapevines: Handbook for detection and diagnosis. FAO, Rome, Italy.

Martinelli, L., Gribaudo, I., 2001: Somatic embryogenesis in grapevine. In: Roubelakis-Angelakis, K. (ed.), Molecular biology \& biotechnology of the grapevine, 327-351. Kluwer Academic Publishers Dordrecht, Boston, London.

Martinelli, L., Gribaudo, I., Bertoldi, D., Candioli, E., Poletti, V., 2001: High efficiency somatic embryogenesis and plant germination in grapevine cultivars Chardonnay and Brachetto a grappolo lungo. Vitis 40, 111-115.

Meng, B., Martelli, G., Golino, D., Fuchs, M., 2017: Grapevine viruses: molecular biology, diagnostics and management. Springer Nature, Cham, Switzerland.

Morgana, C., Di Lorenzo, R., Carimi, F., 2004: Somatic embryogenesis of Vitis vinifera L. (cv. Sugraone) from stigma and style culture. Vitis 43, 169-173.

Mullins, M.G., Srinivasan, C., 1976: Somatic embryos and plantlets from an ancient clone of the grapevine (cv. Cabernet-Sauvignon) by apomixis in vitro. Journal of Experimental Botany 27, 1022-1030.

Murashige, T., Skoog, F., 1962: A revised medium for apid growth and bio assays with tobacco tissue cultures. Physiologia Plantarum 15, 473-497.
Newton, D.J., Goussard, P.G., 1990: The ontogeny of somatic embryos from in vitro cultured grapevine anthers. South African Journal for Enology and Viticulture 11, 70-75.

Nitsch, J.P., Nitsch, C., 1969: Haploid plants from pollen grains. Science 163, 85-87.

Oliver, J.E., Fuchs, M., 2011: Tolerance and resistance to viruses and their vectors in Vitis sp.: A virologist's perspective of the literature. American Journal of Enology and Viticulture 62, 438-451.

Pearce, D., Pharis, R. P., Rajasekaran, K., Mullins, M.G., 1987: Effects of chilling and ABA on $\left[{ }^{3} \mathrm{H}\right]$ gibberellin $\mathrm{A}_{4}$ metabolism in somatic embryos of grape (Vitis vinifera L. $\times V$. rupestris Scheele). Plant Physiology 84, 381-385.

Prado, M.J., Grueiro, M.P., González, M.V., Testillano, P.S., Domínguez, C., López, M., Rey, M., 2010: Efficient plant regeneration through somatic embryogenesis from anthers and ovaries of six autochthonous grapevine cultivars from Galicia (Spain). Scientia Horticulturae 125, 342-352.

Raski, D.J., Goheen, A.C., Lider, L.A., Meredith, C.P., 1983: Strategies against grapevine Fanleaf virus and its nematode vector. Plant Disease 67, 335-339.

Robacker, C., 1993: Somatic embryogenesis and plant regeneration from muscadine grape leaf explants. HortScience 28, 53-55.

Sabella, E., Pierro, R., Luvisi, A., Panattoni, A., D’Onofrio, C., Scalabrelli, G., Nutricati, E., Aprile, A., De Bellis, L., Materazzi, A., 2018: Phylogenetic analysis of viruses in Tuscan Vitis vinifera sylvestris (Gmeli) Hegi. PLoS ONE 13, e0200875.

Salunkhe, C.K., Rao, P.S., Mhatre, M., 1999: Plantlet regeneration via somatic embryogenesis in anther callus of Vitis latifolia L. Plant Cell Reports 18, 670-673.

San Pedro, T., Gammoudi, N., Peiró, R., Olmos, A., Gisbert, C., 2017: Somatic embryogenesis from seeds in a broad range of Vitis vinifera L. varieties: rescue of true-to-type virus-free plants. BMC Plant Biology 17, 226.

Sim, S.T, Golino, D., 2010: Micro- vs. macroshoot tip tissue culture therapy for disease elimination in grapevines. Foundation Plant Services FPS Grape Program Newsletter, 12-15.

Sim, S.T., 2006: Virus elimination from grape selections using tissue culture. Foundation Plant Services. Proceedings of the $17^{\text {th }}$ Congress of ICVG, Davis, California, USA, 30-31.

Stamp, J.A., Meredith, C.P., 1988: Somatic embryogenesis from leaves and anthers of grapevine. Scientia Horticulturae 35, 235-250.

Vončina, D., Al Rwahnih, M., Rowhani, A., Gouran, M., Almeida, R.P.P., 2017: Viral diversity in autochthonous croatian grapevine cultivars. Plant Disease 101, 1230-1235.

Wang, M.R., Cui, Z.H., Li, J.W., Hao, X.Y., Zhao, L., Wang, Q.C., 2018: In vitro thermotherapy-based methods for plant virus eradication. Plant Methods 14, 87.

Xiao, H., Shabanian, M., Moore, C., Li, C., Meng, B., 2018: Survey for major viruses in commercial Vitis vinifera wine grapes in Ontario. Virology Journal 15, 127.

Xu, X., Lu, J., Ren, Z., Wang, H., Leong, S., 2005: Callus induction and somatic embryogenesis in muscadine and seedless bunch grapes (Vitis) from immature ovule culture. Proceedings of the Florida State Horticultural Society 118, 260-262. 